\title{
Effects of drip irrigation system with variation of water source and volume in pepper (Capsicum annuum L.)
}

\author{
Junita Br. Nambela ${ }^{1 *}$, Krisna Margaretta Malau², and Michel Koibur ${ }^{2}$ \\ ${ }^{1}$ Papua Barat Assessment Institute for Agricultural Technology \\ JIn. Trikora Anday, Kompleks Kawasan Terpadu Kementerian Pertanian, Manokwari, West Papua 98315, Indonesia \\ ${ }^{2}$ Manokwari Agricultural Development Polytechnic \\ JIn. SPMA Reremi 143, Manokwari Barat, Kabupaten Manokwari, West Papua 98312, Indonesia \\ *Corresponding author: junitanambela@yahoo.co.id
}

\section{Article Info}

Received : $30^{\text {th }}$ November 2020

Revised : $16^{\text {th }}$ April 2021

Accepted: $02^{\text {nd }}$ June 2021

Keywords:

Horticulture, irrigation, watering

type, watering volume

\begin{abstract}
Water plays the important roles for plants. Besides maintaining the cell turgidity, it also functions as a nutrients solvent for photosythesis process, which affects plant growth. This study aimed to determine the effects of the source and volume of irrigation water with drip irrigation system on the growth of pepper plants in polybags. This research was conducted at the green house of Polbangtan Manokwari, Anday, West Papua from June to October 2020. This research was arranged in a factorial Completely Randomized Design consisting of two treatment factors, namely irrigation water source (PDAM water and ground water) and volume (150 mL per plant, $200 \mathrm{~mL}$ per plant, and $250 \mathrm{~mL}$ per plant). The results showed that PDAM water showed a better effect than groundwater, while the volume of irrigation water applied to pepper plants had no significant effect on plant height, number of leaves, and stem diameter. This situation is thought to be due to genetic factors from the pepper cultivars grown. PDAM water has a better effect because of its high $\mathrm{pH}$ and higher content of Nitrite as $\mathrm{N}$ content. Also, it has lower temperature, lower TDS, and lower iron contents. Meanwhile, irrigation water volume of $250 \mathrm{~mL}$ per plant per day has a minimal risk of plant drought compared to other treatments.
\end{abstract}

\section{INTRODUCTION}

The availability of water is very vital for plants since it functions as a solvent for nutrient elements contained in the soil to be easily taken up by plants through the roots and transported to parts of the plant (including photosynthetic leaves) via xylem. Besides, it also plays a role as a solvent for photosynthate to be distributed to all parts of the plant through the phloem and used by plants for the growth process (Song and Banyo, 2011).

Drought is one of the environmental stresses that can cause stunted growth and development, as well as decreasing plant productivity (Song and Banyo, 2011; Setiawan and Shiddieq, 2012). Water deficit in plants will lead to a decline in growth and death (Anggraini et al., 2015). In addition, the lack of groundwater will inhibit nutrient transport to the leaves, thereby decreasing crop production (Maryani, 2012).

Growth is achieved through cell division, enlargement, and differentiation, involving genetic, physiological, ecological and morphological events and their complex interactions. The quality and quantity of plant growth depend on these events, which are affected by water deficit (Farooq et al., 2009). Provision of water below the optimum requirement will lead to plant adaptation by modifying the size and shape of its organs. This is consistent with Felania (2017) who stated that the

\footnotetext{
How to cite: Nambela, J.B., Malau, K.M., and Koibur, M. (2021). Effects of drip irrigation system with variation of water source and volume in pepper (Capsicum annum L.) . Ilmu Pertanian (Agricultural Science), 6(3), pp. 184-190.
} 
effect of water stress on plant growth was reflected in smaller leaves. This is a plant avoidance mechanism to suppress water loss to reduce transpiration in plants. Meanwhile, there are several ways that plants can do to respond to water shortages, one of which is by reducing root elongation, penetration depth and root diameter for plants that are intolerant of water deficiency, while those that are tolerant to water deficiency respond by having more roots, greater volume of roots, and a large ratio of roots to shoots (Haryati, 2008). Plants will also shed their leaves in extreme drought conditions (Yuniarsih, 2017). Drought stress conditions will cause plants to be widely affected, starting from gene expression, metabolism, and growth (Pratiwi, 2016).

Drought stress is a limiting factor for plants growth and development (Wang et al., 2012). Research results by Nugraha et al. (2014) found that water stress in the vegetative phase resulted in the decreased growth and yield of soybeans more than stress during the generative phase. In line with that, Marsha et al. (2014) stated that Crotalaria mucronata Desv. could grow well in conditions of $75 \%$ of field capacity. One solution to overcome the uncertain condition of water availability is the use of irrigation technologies on agricultural lands, on of which is drip irrigation system. Drip irrigation is a method of providing a continuous supply of water with low discharge. Mechanically, the water is distributed through a pipe network, which is then given to the root area in an amount close to the plant's need through a dropper (emitter), namely certain small holes equidistant along the pipeline. This system is suitable to be applied in agricultural areas that have limited water sources (Sumarna, 1998).

In essence, drip irrigation can be applied in areas where water is very limited or expensive, areas in which the soils are sandy, rocky or difficult to level and, areas with high-economic-valued plants (Sapei, 2006). Pepper is a plant with high economic value because of its uses for food and raw material for the pharmaceutical industry including medicinal herbs, cosmetics, and food coloring (Sobari, 2014). This plant is very suitable to be cultivated with a drip irrigation system in order to have effective and efficient use of irrigation water. Based on these problems, this study aimed to determine the effects of the source and volume of irrigation water with drip irrigation systems on the growth of pepper plants in polybags.

\section{MATERIALS AND METHODS}

This research was conducted at the green house of the Manokwari Agricultural Development Polytechnic, the Ministry of Agriculture Integrated Area Complex, Anday, South Manokwari, Manokwari Regency, West Papua from June 2020 to October 2020.

The materials used in this study were pepper seeds, drip irrigation installation, top soil, compost, NPK fertilizer, stakes, wire, paranet, and seed trays. The tools used were 1,100 L water tendon, water pump, hoe, meter, calipers, stationery, etc.

This study was arranged in a factorial Completely Randomized Design (CRD) consisting of two treatment factors, namely irrigation water source comprising PDAM water and groundwater and volume consisting of $150 \mathrm{~mL}$ per plant per day, $200 \mathrm{~mL}$ per plant per day, and $250 \mathrm{~mL}$ per plant per day. There were 20 replications in this study so that there were a total of 120 pepper polybags. Research data were analyzed using ANOVA, and those showing significant effect were subjected to Duncan's Multiple Range Test (DMRT) at $\mathrm{a}=5 \%$.

The planting medium was a mixture of top soil and compost with a ratio of $1: 1$. Top soil and compost were mixed evenly and put in polybags. The polybag size used was $25 \mathrm{~cm} \times 30 \mathrm{~cm}$. The volume of planting media loaded into the polybag was $3.768 \mathrm{~L}$ in each polybag. Basic fertilization was carried out when the plants were two weeks after planting and repeated every two weeks. The dose of NPK fertilization was $25 \mathrm{~g}$ per polybag. The fertilizer was applied around the roots with a distance around of $4 \mathrm{~cm}$ from the main stem of the pepper.

The variables observed included plant height, number of leaves, and stem diameter, and the data were taken three times, which were two weeks after planting, four weeks after planting, and six weeks after planting. Plant height was measured from the ground surface near the roots to the tip of the leaf, which is pulled straight up, in centimeters $(\mathrm{cm})$. The number of leaves counted was the number of plant leaves that had been fully developed and complete (having midrib, stem and leaf blade) in strands. The diameter of the stem was measured by measuring the circumference of the pepper main stem near the root using a caliper in millimeters (mm). 


\section{RESULTS AND DISCUSSION}

The results of analysis of variance from the vegetative growth variables of pepper plants are presented in Table 1 - Table 4. The effects of treatments on the plant height are shown in Table 1.

Based on Table 1, the treatments of irrigation water source and volume at 2 WAP and 4 WAP did not have a significant effect on the average height of pepper plants. This is presumably because at the beginning of the growth period up to 4 WAP, plants needed water in small amounts so that it was easily fulfilled. It was different when the plants got bigger (6 WAP). The more complex and large the crosssectional area of plants, the more nutrients and water they need for metabolism and life processes. Therefore, it is recommended to increase the volume of irrigation in line with the increasing rate of plant growth. Likewise, water volume at 6 WAP did not gave significant effect on the plant height of pepper. However, there was a significant effect of irrigation water resource on the plant height, in which PDAM Water showed the higher value of plant heighty $(49.53 \mathrm{~cm})$ compared to groundwater $(36.81 \mathrm{~cm})$.

Furthermore, there are no direct comparative studies that can be referred to compare the differences in the effects of PDAM water and groundwater on the pepper growth. However, indirect comparative studies comparing the effects of rainwater and surface water have found that rainwater had a better effect on mungbean plant (Rajab, 2016). Rainwater has the best effect on plants because it contains a lot of free $\mathrm{N}$ (nitrogen) and minimum contamination compared to surface water. The results of this study

Table 1. Effects of irrigation water source and volume treatments on the plant height $(\mathrm{cm})$

\begin{tabular}{lccc}
\hline \multirow{2}{*}{ Treatments } & \multicolumn{3}{c}{ Observation time } \\
\cline { 2 - 4 } & 2 WAP & 4 WAP & 6 WAP \\
\hline Water sources & $17.11 \mathrm{a}$ & $31.71 \mathrm{a}$ & $49.53 \mathrm{a}$ \\
PDAM Water & $16.97 \mathrm{a}$ & $34.60 \mathrm{a}$ & $36.81 \mathrm{~b}$ \\
Groundwater & & & \\
\hline Water volume & $17.27 \mathrm{~d}$ & $32.78 \mathrm{~d}$ & $42.52 \mathrm{~d}$ \\
$150 \mathrm{~mL}$ per plant per day & $16.24 \mathrm{~d}$ & $31.38 \mathrm{~d}$ & $39.99 \mathrm{~d}$ \\
$200 \mathrm{~mL}$ per plant per day & $17.60 \mathrm{~d}$ & $35.31 \mathrm{~d}$ & $47.02 \mathrm{~d}$ \\
\hline
\end{tabular}

Remarks: Means followed by the same letters in the same column are not significantly different according to Duncan Multiple Range Test $\mathrm{a}=$ $5 \%$, WAP $=$ Weeks After Planting

Table 2. Effects of irrigation water source and volume treatments on the number of leaves

\begin{tabular}{lccc}
\hline \multirow{2}{*}{ Treatments } & \multicolumn{3}{c}{ Observation time } \\
\cline { 2 - 4 } & 2 WAP & 4 WAP & 6 WAP \\
\hline Water sources & $5.60 \mathrm{a}$ & $9.12 \mathrm{a}$ & $10.23 \mathrm{~b}$ \\
PDAM Water & $5.23 \mathrm{a}$ & $7.10 \mathrm{~b}$ & $12.77 \mathrm{a}$ \\
Groundwater & & & \\
\hline Water volume & $5.83 \mathrm{~d}$ & $7.73 \mathrm{~d}$ & $10.71 \mathrm{~d}$ \\
$150 \mathrm{~mL}$ per plant per day & $5.13 \mathrm{e}$ & $8.46 \mathrm{~d}$ & $11.05 \mathrm{~d}$ \\
$200 \mathrm{~mL}$ per plant per day & $5.28 \mathrm{e}$ & $8.13 \mathrm{~d}$ & $12.73 \mathrm{~d}$ \\
\hline
\end{tabular}

Remarks: Means followed by the same letters in the same column are not significantly different according to Duncan Multiple Range Test $a=$ $5 \%$, WAP $=$ Weeks After Planting 
also showed that peppers height was not significant with different water sources and water volumes given. This situation is thought to be due to genetic factors from the peppers cultivars planted. This is in accordance with the statement (Maulana and Idrus, 2010) that plant height may not be influenced by the adequacy of the given water, but is controlled by genetic factors of the cultivar planted.

Table 2 showed that irrigation water source had a significant effect on the average number of plant leaves at 4 and 6 WAP, while at 2 WAP, it had no significant effect on the number of leaves of the pepper. The highest number of leaves consecutively at all observation times were: 5.60; 9.12; and 12.77. The number of pepper leaves will affect the volume of irrigation water needed. This is in accordance with Hamim (2019), stating that the higher the difference in water vapor concentration between space in the stomata and free air, the greater the transpiration rate of the plant. The amount of the transpiration rate of a plant species is determined by several factors. Factors in plants that affect transpiration are the number and size of stomata as well as the number and area of leaves. Accordingly, Kapoor et al. (2020) stated that plant drought tolerance encompasses alterations at morphological levels like reduced leaf area or leaf rolling and continued to the leaf abscission as form of high drought tolerance.

Besides, the average number of pepper leaves is significantly affected by the volume of irrigation water at 2 WAP (Table 2). The highest average number of leaves was found in the provision of 150 $\mathrm{mL}$ per plant per day with irrigation water volume (5.83 leaves). However, at 4 WAP and 6 WAP, the water volume did not give significant effect on the

Table 3. Effects of irrigation water source and volume treatments on the stem diameter $(\mathrm{mm})$ at 2 WAP and 4 WAP

\begin{tabular}{lll}
\hline \multirow{2}{*}{ Treatments } & \multicolumn{2}{c}{ Observation time } \\
\cline { 2 - 3 } & \multicolumn{1}{c}{2 WAP } & \multicolumn{1}{c}{4 WAP } \\
\hline PDAM water $150 \mathrm{~mL}$ per plant per day & $2.03 \mathrm{a}$ & $3.48 \mathrm{abc}$ \\
PDAM water $200 \mathrm{~mL}$ per plant per day & $1.60 \mathrm{c}$ & $2.90 \mathrm{c}$ \\
PDAM water $250 \mathrm{~mL}$ per plant per day & $1.89 \mathrm{ab}$ & $3.92 \mathrm{a}$ \\
Groundwater $150 \mathrm{~mL}$ per plant per day & $1.87 \mathrm{ab}$ & $3.60 \mathrm{ab}$ \\
Groundwater $200 \mathrm{~mL}$ per plant per day & $1.94 \mathrm{a}$ & $3.33 \mathrm{abc}$ \\
Groundwater $250 \mathrm{~mL}$ per plant per day & $1.73 \mathrm{bc}$ & $3.09 \mathrm{bc}$ \\
\hline
\end{tabular}

Remarks: Means followed by the same letters in the same column are not significantly different according to Duncan Multiple Range Test $a=$ $5 \%$, WAP $=$ Weeks After Planting

Table 4. Effects of irrigation water source and volume treatments on the stem diameter $(\mathrm{mm})$ at 6 WAP

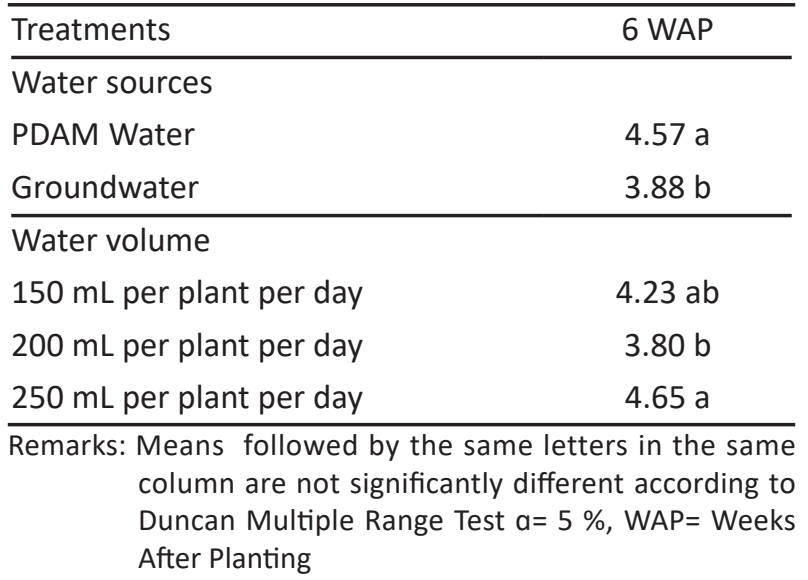


leaves number parameter.

Table 3 showed the interaction between irrigation water source and volume has significant effect on the stem diameter of pepper at 2 WAP and 4 WAP. The the largest stem diameter was obtained in the treatment of $150 \mathrm{~mL}$ PDAM water $(2.03 \mathrm{~mm})$ at 2 WAP and $250 \mathrm{~mL}$ PDAM water $(3.92 \mathrm{~mm}$ ) at 4 WAP. Meanwhile, the smallest stem diameter was found in $200 \mathrm{~mL}$ PDAM water both for 2 WAP and 4 WAP, which was $1.60 \mathrm{~mm}$ and $2.90 \mathrm{~mm}$, respectively.

At 6 WAP, the interaction of irrigation water source and volume did not significantly affect the diameter of the pepper stems (Table 4). However, PDAM water gave better efect than groundwater, and irrigation volume of $250 \mathrm{~mL}$ per plant per day gave better effect than irrigation volume of $150 \mathrm{~mL}$ per plant per day and $200 \mathrm{~mL}$ per plant per day. This is in line with the research of Wahb-Allah et al. (2011), reporting that a small volume of water would decrease the rate of plant growth.

Irrigation using PDAM water gave better results compared to using groundwater. The faster growth of pepper is caused by water containing higher levels of nutrients, especially those rich in nitrogen. The nitrogen concentration in PDAM water is higher because this water has a higher content of nitrite as $\mathrm{N}$ than gorundwater (Table 5 ). The transformation of this nitrite compound will dissolve in irrigation water. This is in accordance with Wantasen et al. (2012), stating that the impact of nitrogen transformation (nitrate, nitrite, and ammonia) on the biotic environment is the fertilization of waters so that it causes better growth. Nitrite ( $\left.\mathrm{NO}^{2-}\right)$ in water is formed from one nitrogen atom and two oxygen atoms. Aerobic conditions will cause nitrite to turn into more nitrogen, which is needed by plants especially in the growth process such as stem diameter.

In addition, PDAM water that is better used as irrigation water is allegedly due to its lower initial temperature because it comes from higher ground. The temperature of PDAM water was $19.2^{\circ} \mathrm{C}$, while that of groundwater was $25.3^{\circ} \mathrm{C}$. Water temperature can change due to the removal of water from the research area during the transport to the laboratory so that the water to be studied was exposed to sunlight, causing the temperature to increase. According to Gusril (2016), it was recommended that the water temperature absorbed by plants was $10{ }^{\circ} \mathrm{C}$ to $25^{\circ} \mathrm{C}$ (cool) so that there was no dissolution of chemical substances in the channel or pipe that can affect the chemical processes in pepper plants. When plants are at a higher temperature, the enzyme performance will be impaired. As a result, respiration and transport of substances are disrupted. This can cause nutritional deficiencies in plants. At high temperatures, less water can be absorbed by plants, but evaporation will occur more easily.

Moreover, the TDS value was smaller (100 mg. $\mathrm{L}^{-1}$ ) so that the electrical conductivity was smaller; and a greater $\mathrm{pH}$ value $(\mathrm{pH} 8)$ so it is better for plants. Water conditions that are more alkaline are considered better for neutralizing the acidity of the soil or planting media, as stated by Astuti (2014) which states that there is an interrelated relationship between electrical conductivity (DHL), TDS and $\mathrm{pH}$ of irrigation water where the value of one parameter will affect other parameters. Beside that, the iron (Fe) content in PDAM water is also smaller than well water. Iron levels are needed in relatively small amounts for plants and tend to have a negative effect if they are present in excess amounts because they can toxic for plants.

Table 5. Physical and chemical test results for PDAM water and groundwater

\begin{tabular}{|c|c|c|c|c|c|}
\hline \multirow[b]{2}{*}{ Parameters } & \multirow[b]{2}{*}{ Unit } & \multirow{2}{*}{$\begin{array}{l}\text { Maximum } \\
\text { level }\end{array}$} & \multicolumn{2}{|c|}{ Result } & \multirow[b]{2}{*}{ Methods } \\
\hline & & & \multicolumn{2}{|c|}{ PDAM water $^{1}$ Groundwater $^{2}$} & \\
\hline Temperature & ${ }^{\circ} \mathrm{C}$ & 30 & 19.2 & 25.3 & SNI 06-6989.23-2005 \\
\hline TDS* & $\mathrm{mg} \cdot \mathrm{L}^{-1}$ & 1000 & 100 & 348 & SNI 06-2413-1991 \\
\hline $\mathrm{pH}$ & - & $6.5-8.5$ & 8 & 7.9 & SNI 06-2413-1991 \\
\hline Iron (Fe) & $\mathrm{mg} \cdot \mathrm{L}^{-1}$ & 1 & 0.01 & 0.019 & 3500-B, 3120-B, 330-E \\
\hline Nitrite as Nitrogen & $\mathrm{mg} \cdot \mathrm{L}^{-1}$ & 1 & 5 & 0.04 & - \\
\hline
\end{tabular}

Remarks: ${ }^{1}$ The PDAM water tested at The Water Laboratory of the Manokwari District Health Office, ${ }^{2}$ The groundwater tested at The Environmental Laboratory of Sucofindo Bekasi, West Java, *TDS = Total Dissolve Solid 
Irrigation aspect is very important for the growth of pepper plants. Previous research by Manan and Al Machfudz (2015) showed that the volume of irrigation water had a significant effect on the plant height, stem diameter, number of leaves, leaf area, and plant fresh weight, thereby affecting the vegetative growth of plants. This can be interpreted that plant growth is very sensitive to water deficit because it is associated with turgor, and the loss of turgidity can stop cell division and enlargement, which results in stunted plant growth including stem diameter. Therefore, the effects of the irrigation water source and volume on the three growth variables of pepper can directly affect the yield. This is in accordance with Hermanto et al. (2014), reporting that watering once a day could increase the diameter of the stem compared to watering every two and three days. In addition, a similar study on oil palm perennial crops found that proper irrigation treatment could lead to better growth in canopy, as a result of optimal conditions for the development of yields. In line with that, Kolo \& Tri (2016) found that in tomatoes, the frequency of watering had a significant effect on the stem diameter where the plant stems that were watered every day were always the largest and significantly different from the diameter of the plant stems watered every five days (Azarpanah et al. (2013).

\section{CONCLUSIONS}

In general, PDAM water showed a better effect than groundwater, while the volume of irrigation water applied to pepper plants had no significant effect on plant height, number of leaves, and stem diameter. This situation is thought to be due to genetic factors from the pepper cultivars grown. PDAM water has a better effect due to several conditions, such as higher nitrite content, higher $\mathrm{pH}$, lower temperature, lower TDS value, and lower iron content. Meanwhile, irrigation water volume of 250 $\mathrm{mL}$ per plant per day has a minimal risk of plant drought compared to other treatments.

\section{ACKNOWLEDGMENTS}

This research is a research funded by the 2020 Strategic Research Program by the Education Center of the Ministry of Agriculture, conducted in collaboration between the Manokwari Agricultural
Development Polytechnic and the West Papua Assessment Institute for Agricultural Technology. The authors would like to thank PDAM Manokwari for the cooperation and also to Subiadi, Igit Atang Sunante and Steven Witman for their technical helps.

\section{REFERENCES}

Anggraini, N., Faridah, N., and Indrioko, S. (2015). Pengaruh cekaman kekeringan terhadap perilaku fisiologi dan pertumbuhan bibit black locust (Robinia pseudoacacia). Jurnal IImu Kehutanan, 9(1), pp. 41-46.

Astuti, A.D. (2014). Kualitas air irigasi ditinjau dari parameter DHL, TDS, pH, pada lahan sawah Desa Bulumanis Kidul Kecamatan Margoyoso. Jurnal Litbang, 10(1), pp. 35-42.

Azarpanah, A., Alizadeh, O., Dehghanzadeh, H., and Zare, M. (2013). The effect of irrigation levels in various growth stages on morphological characteristics and yield of Zea mays L. Tech. J. Engin. \& App. Sci., 3(14), pp. 1447-1459.

Farooq, M., Wahid, A., Kobayashi, N., Fujita, D., and Basra, S.M.A. (2009). Plant drought stress: effects, mechanisms and management. Agronomy Sustainable Development, 29, pp. 185-212.

Felania, C. (2017). Pengaruh ketersediaan air terhadap pertumbuhan kacang hijau (Phaceolus radiatus). Prosiding Seminar Nasional Pendidikan Biologi dan Biologi. Universitas Negeri Yogyakarta. Yogyakarta. pp. 131-138.

Gusril, H. (2016). Studi kualitas air minum PDAM di Kota Duri Riau. Jurnal Geografi, 8(2), pp. 190196.

Hamim. (2019). Fisiologi Tumbuhan. $2^{\text {nd }}$ ed. Universitas Terbuka, Jakarta, pp. 1-51.

Haryati. (2003). Pengaruh cekaman air terhadap pertumbuhan dan hasil tanaman. Undergraduated Thesis. Faculty of Agriculture Universitas Sumatera Utara. Medan.

Hermanto, Sitepu, F.E., and Ginting, J. (2014). Pertumbuhan bibit kelapa sawit (Elaesis guineensis Jacq.) dengan menggunakan media sekam padi dan frekuensi penyiraman di main nursery. Jurnal Agroteknologi, 2(3), pp. 1211-1218.

Kapoor, D., Bhardwaj, S., Landi, M., Sharma, A., Ramakrishnan, M., and Sharma, A. (2020). Review: the impact of drought in plant metabolism: how to exploit tolerance 
mechanisms to increase crop production. Applied Science, 10(16), pp. 1-19.

Kolo, A. and Tri, K. (2016). Pengaruh pemberian arang sekam padi dan frekuensi penyiraman terhadap pertumbuhan dan hasil tanaman tomat (Lycopercicom esculentum Mill). Savana Cendana Jurnal Pertanian Konservasi Lahan Kering, 1(3), pp. 102-104.

Marsha, N.D, Aini, N., and Sumarni T. (2014). Pengaruh frekuensi dan volume pemebrian air pada pertumbuhan tanaman Crotalaria mucronata Desv. Jurnal Produksi Tanaman, 2(8), pp.673-678.

Maryani, A.T. (2012). Pengaruh volume pemberian air terhadap pertumbuhan bibit kelapa sawit di pembibitan utama. Jurnal Fakultas Pertanian Universitas Jambi Mendolo Darat, 1(2), pp. 65.

Maulana E. and Idrus, M. (2010). Pengaruh Interval Waktu Pemberian Air terhadap Produktivitas Tanaman Tomat Di Lahan kering Dataran Rendah pada Musim Kemarau. Jurnal Penelitian Pertanian Terapan, 10(3), pp. 207-212.

Manan, A.A. and Al Mahfudz, W.D.P. (2015). Pengaruh volume air dan pola vertikultur terhadap pertumbuhan dan hasil sawi hijau (Brassica juncea L.). Jurnal Agroteknologi, 12(1), pp. 33-43.

Nugraha, Y.S., Sumarni, T., and Sulistyono, R. (2014). Pengaruh interval waktu dan tingkat pemberian air terhadap pertumbuhan dan hasil tanaman kedelai (Glycine max (L.) Merill). Jurnal Produksi Tanaman, 2(7), pp. 552-559.

Pratiwi, A.R. (2016). Kajian efek poly ethylene glycol (PEG) 6000 terhadap cekaman kekeringan planlet kedelai (Glycine max (L.) Merill) varietas tanggamus secara in vitro. Undergraduated Thesis. Universitas Lampung.

Rajab, M.A. (2016). Pengaruh pertumbuhan kacang hijau (Phaseolus radiatus) dengan perlakuan pemberian media air berbeda. Undergraduated Thesis. Universitas Cokroaminoto Palopo.
Sapei, A. (2006). Irigasi tetes. $1^{\text {st }}$ ed. Bagian Teknik Tanah dan Air Departemen Teknik Pertanian Fateta Institut Pertanian Bogor, Bogor. pp. 1-44.

Setiawan, T. and Shiddieq, D. (2012). Pengaruh cekaman kekeringan terhadap akumulasi prolin tanaman nilam (Pogostemon cablin Benth.). Ilmu Pertanian (Agricultural Science), 15(2), pp. 85-99.

Sobari, E. (2014). Budidaya pepper: analisis pada bangunan screen house dengan sistem drip irrigation. $1^{\text {st }}$ ed. Graha Ilmu: Yogyakarta. pp. 1-8.

Song, N. and Banyo, Y. (2011). Konsentrasi klorofil daun sebagai indikator kekurangan air pada tanaman. Jurnal IImiah Sains, 11(2), pp. 169170.

Sumarna, A. (1998). Irigasi tetes pada budidaya cabai. Monograf No.09. $1^{\text {st }}$ ed. Balai Penelitian Tanaman Sayuran Pusat Penelitian dan Pengembangan Hortikultura, Bandung. pp. 1-31.

Wahb-Allah M.A., Alsadon A.A., and Ibrahim, A.A. (2011). Drought tolerance of several tomato genotypes under greenhouse condition. World Applied Science Journal, 15(7), pp. 933-940.

Wang, C.J., Yang, W., Wang, C., Gu, C., Niu, D.D., Liu, H.X., Wang, Y.P., and Guo, J.H. (2012). Induction of drought tolerance in cucumber plants by a consortium of three plant growth-promoting Rhizobacterium strains. Plos One, 7(12), e52565.

Wantasen, S., Sudarmadji, Sugiharto, E., and Suprayogi, S. (2012). Dampak transformasi nitrogen terhadap lingkungan biotik di Danau Tondano Provinsi Sulawesi Utara. Jurnal Manusia dan Lingkungan, 19(2), pp. 143-149.

Yuniarsih, D. (2017). Pengaruh cekaman air terhadap kandungan protein kacang kedelai. Prosiding Seminar Nasional Pendidikan Biologi dan Biologi Universitas Negeri Yogyakarta, pp. 111-122. 